\title{
CONTROLS OF GRASS AND SHRUB ABOVEGROUND PRODUCTION IN THE PATAGONIAN STEPPE
}

\author{
Esteban G. JobbÁGY ${ }^{1}$ And Osvaldo E. Sala \\ IFEVA-Departamento de Ecología, Facultad de Agronomía, Universidad de Buenos Aires, Avenida San Martín 4453, \\ 1417 Buenos Aires, Argentina
}

\begin{abstract}
We studied the temporal dynamics of aboveground net primary production (ANPP) and senescence in a semiarid steppe representative of the Occidental District of Patagonia. We focused on the association of ANPP and senescence with climatic fluctuations at annual and seasonal scales. We estimated annual ANPP based on biomass harvests of grasses and shrubs (the dominant functional groups) at the peak of the growing season (January). The ANPP and senescence of grasses alone were also estimated for several periods within each year.

The mean annual ANPP of the studied community for 10 years was $56 \mathrm{~g} \cdot \mathrm{m}^{-2} \cdot \mathrm{yr}^{-1}$, and the coefficient of variation was $26 \%$. Grass and shrub mean annual ANPP had similar levels. Annual shrub production was associated with cumulative precipitation for the whole year, whereas annual grass production was not associated with precipitation. The average seasonal dynamics of grass ANPP showed its peak during spring, and there was no grass production during late summer and early fall. The peak green biomass of grass was achieved in early summer. Average senescence rates were more constant throughout the year, except for winter, when senescence was almost interrupted. Winter grass ANPP was positively associated with fall temperature, spring grass ANPP was positively related to winter precipitation, and summer grass ANPP was positively related to spring precipitation. Grass senescence during spring was negatively related to precipitation in the same season.

Our results highlight the importance of separating functional types in productivity studies. The differential effect of precipitation on grass and shrub ANPP masked the association when these functional groups were pooled. ANPP association with climatic variables in the Occidental District of the Patagonian steppe shifted from precipitation alone to precipitation and temperature when the temporal scale of analysis changed from annual to seasonal.
\end{abstract}

Key words: aboveground net primary production (ANPP); arid ecosystem; cold deserts; Patagonia (Argentina); plant functional types; primary production; rangelands; seasonality; senescence.

\section{INTRODUCTION}

Net primary production represents the main energy input of ecosystems (Odum 1971) and has been proposed as an integrative variable of whole-ecosystem functioning (McNaughton et al. 1989). In rangeland ecosystems, the amount and seasonality of aboveground net primary production (ANPP) determine forage availability, constrain herbivore carrying capacity, and shape grazing strategies.

What are the controls of ANPP? Can we predict ANPP levels? These are questions of value for ecologists and range scientists attempting to understand the functioning of rangelands and to design sustainable ways to use them. In this paper, we explore these questions for the Occidental District of the Patagonian steppe, a semiarid rangeland that occupies $90000 \mathrm{~km}^{2}$ of the southern portion of South America (Soriano 1983).

Manuscript received 30 October 1998; revised and accepted 22 June 1999.

${ }^{1}$ Present address: Department of Botany, Phytotron Building, Duke University, Durham, North Carolina 27708 USA. E-mail: e.jobbagy@duke.edu
Most of our current knowledge about the controls of ANPP derives from correlative regional analyses. They highlight the importance of mean annual precipitation in explaining changes of average ANPP across broad spatial gradients in several continents (Webb et al. 1978, 1983, Lauenroth 1979, Sala et al. 1988b, McNaughton et al. 1993, Paruelo et al. 1998). In order to predict ANPP, understanding its controls through time is required. Unfortunately, ANPP controls through time are more elusive than the controls across space. In some cases, annual precipitation explains year-to-year ANPP changes, but usually this relationship has lower correlation levels and slopes than that for spatial gradients (Smoliak 1986, Le Houérou et al. 1988, Lauenroth and Sala 1992).

Current ecological theory highlights the importance of identifying plant functional types for ecosystem studies (Chapin 1993). The responses of plants to the environment vary consistently among functional types. Therefore, the controls of ANPP may vary according to the functional type considered. Most ANPP studies ignore this fact and consider the whole community as a pool. 
The Patagonian steppe is a cold, semiarid region. Precipitation occurs mainly during fall and winter and recharges the soil profile almost every year, wetting the deep soil layers. Spring and summer precipitation events are rare and only wet the upper soil layers (Sala et al. 1989, Paruelo and Sala 1995). Grasses and shrubs are the dominant plant functional types of the steppes of the Occidental District (Soriano 1956, Golluscio et al. 1982). These functional types have contrasting rooting systems, phenologies, and water utilization patterns. Grasses have shallow roots and green leaves all year round (Soriano et al. 1987). Shrubs have deep roots and include deciduous and evergreen species (Fernández and Paruelo 1988). Previous studies have shown a lag between the rainy season (fall-winter) and onset of the growing season (spring) (Deffosé et al. 1990, Fernández et al. 1991).

Several specific questions guided our exploration of ANPP controls and the evaluation of potential forecasting of ANPP in the Occidental District of the Patagonian steppe. (1) What are the average levels and the variability of grass and shrub annual ANPP? (2) How do grass and shrub annual ANPP respond to precipitation inputs occurring in different times of the year? (3) What are the seasonal patterns of ANPP and senescence? (4) Are the controls of ANPP and senescence the same among seasons? The first two questions deal with the patterns and controls of ANPP dynamics at the annual scale. In this case, we considered the two dominant functional types of the system: grasses and shrubs. The last two questions focus on the patterns and controls of ANPP at the seasonal scale. At this scale, we focused on the production and senescence of grasses.

We explored these questions by studying the natural fluctuations of plant biomass and climate in the field. We based our study on a 15-yr data set of biomass harvests obtained for the most important community of the Occidental District of the Patagonian steppe. We described ANPP patterns and then analyzed their relationship with precipitation and temperature fluctuations at both temporal scales.

\section{Materials and Methods}

The study site is located close to Río Mayo, Chubut (Argentina), at $45^{\circ} 41^{\prime} \mathrm{S}$ and $70^{\circ} 16^{\prime} \mathrm{W}$ at an elevation of $500 \mathrm{~m}$. The area is a flat plateau where long-term mean annual precipitation and temperature are $152 \mathrm{~mm}$ and $8.1^{\circ} \mathrm{C}$, respectively. More than $70 \%$ of the precipitation occurs during fall and winter (Jobbágy et al. 1995). The soil is coarse textured, with pebbles composing $\sim 50 \%$ of the soil mass (Paruelo et al. 1988). Biomass measurements were performed on an area representative of the most typical community of the Occidental District of the Patagonian steppe (Soriano 1956, Golluscio et al. 1982). This steppe community is codominated by grasses and shrubs, which have a total aerial cover of $25 \%$ and $12 \%$, respectively (Fer- nández et al. 1991). The dominant grasses in order of importance are Stipa speciosa Trin. Et Rupr., Poa ligularis Nees ap. Steud., and Stipa humilis Vahl. The dominant shrubs are Senecio filaginoides DC., Mulinum spinosum (Cav.) Pers., and Adesmia campestris (Rendle) Skottsb. Shrubs and grasses in this community account for $>96 \%$ of the canopy cover and biomass (Golluscio et al. 1982, Golluscio and Sala 1993).

We analyzed original and previously published data (Soriano et al. 1976, Ares 1978, Fernández et al. 1991). Methods for biomass measurement were consistent through time. In the case of grasses, $200.2 \times 5 \mathrm{~m}$ plots were randomly located and harvested. This plot shape was used because it reduces sampling variance by encompassing a large proportion of the community heterogeneity (see Soriano et al. 1994). Grass biomass was divided into three categories (green, recent dead, and old dead) and then was oven-dried and weighed. Shrub biomass was estimated by the sampling method of Fernández et al. (1991). Twenty individuals of each dominant shrub species were randomly selected. We measured the height and two orthogonal diameters of each one of these shrubs and harvested the green biomass and the current-year twigs from a $0.1 \times 0.25 \mathrm{~m}$ plot projected vertically to the center of the shrub. The biomass of each shrub individual was estimated assuming a hemispherical shape. The total biomass for each shrub species was calculated as the product of the mean individual biomass and the species density. Shrub density was estimated with the closest individual method, using the distance to random positions along four transects that encompassed $\sim 100$ shrub individuals each (GreigSmith 1983, Fernández et al. 1991). This method underestimates density under clustered distributions, but shrub individuals in this community tend to be distributed randomly. Large herbivores were excluded from the harvest sites. Our data set included annual harvests of grass biomass for 15 years and of shrub biomass for 10 years. Grass biomass was measured with a seasonal frequency during 7 years.

To answer questions about annual production, we used single biomass measurements at the end of the growing season (January) as estimates of annual ANPP. We considered green biomass for grasses and currentyear leaf and twig biomass for shrubs, which were easily recognized by direct observation of color and structure. We regressed peak green biomass vs. precipitation and temperature, considering sum and mean, respectively, for 1-24 mo prior to the date of peak green biomass (January). We evaluated the association between the ANPP of contiguous years. We compared the coefficients of variation of ANPP among functional types using Levene's test for relative variation based on the absolute deviations of each value from the series median, standardized by the median (Brown and Forsythe 1974, Schultz 1985).

We explored questions about seasonality of production only for grasses. We estimated seasonal grass 
TABLE 1. Criteria for aboveground net primary production (ANPP) and senescence estimates in Patagonian steppe. Two grass biomass fractions were taken into account: green $(\mathrm{G})$ and standing dead (SD).

\begin{tabular}{|c|c|c|}
\hline If & delta $G>0$ & delta $\mathrm{G}<0$ \\
\hline 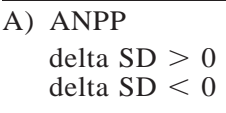 & $\begin{array}{l}\text { delta } G+\text { delta } S D \\
\text { delta } G\end{array}$ & $\begin{array}{l}\text { If delta } G+\text { delta } S D>0 \text {, delta } G+\text { delta } S D \\
0\end{array}$ \\
\hline B) $\begin{array}{l}\text { Senescence } \\
\text { delta } \mathrm{SD}>0 \\
\text { delta } \mathrm{SD}<0\end{array}$ & $\begin{array}{l}\text { delta SD } \\
0\end{array}$ & $\begin{array}{l}\text { If delta } \mathrm{G}+\text { delta } \mathrm{SD}>0 \text {, delta } \mathrm{SD} \\
- \text { delta } \mathrm{G}\end{array}$ \\
\hline
\end{tabular}

Notes: Biomass deltas were estimated for each fraction between sampling dates. The calculation of aboveground net primary production and senescence for each interval between sampling dates varied according to the sign of green and standing dead biomass deltas; the algorithms are presented in the table cells. These criteria were adapted from Singh et al. (1975).

ANPP and senescence, considering green and standing dead biomass changes for grass between consecutive seasonal samplings during 7 years (3-5 samplings per year). All of the biomass differences were corrected for overestimate biases according to Sala et al. (1988a). We computed ANPP or senescence from changes in green and standing dead biomass (Table 1) using an adaptation of criteria from Singh et al. (1975).

We described the average seasonal pattern of grass ANPP and senescence. Because periods between sampling dates had variable duration and were not exactly repeated each year, we divided the cumulative ANPP and senescence values of each period by the number of days within the period, obtaining daily ANPP and senescence values. We estimated the mean and variability of daily ANPP and senescence for each calendar day across the successive growing seasons. We obtained seasonal curves for the mean and the variability of grass ANPP and senescence with a daily resolution. These seasonal curves were smoothed using a 30-d centered moving average.

For each season, we evaluated the association of grass ANPP and senescence with precipitation and temperature. We summed daily ANPP and senescence for each season. Seasons were considered as follows: summer, 1 January to 31 March; fall, 1 April to 30 June; winter, 1 July to 30 September; spring, 1 October to 31 December. We considered the effect of precipitation and temperature during the current and the previous three seasons.

\section{RESULTS}

Annual grass and shrub ANPP had similar values ( $n$ $=10, t=0.55, P=0.28)$. The interannual $\mathrm{CV}$ of annual ANPP was higher for grasses, intermediate for shrubs, and lower for their pooled value (Table 2), with the difference between the $\mathrm{CV}$ of grass and total ANPP being significant (Levene's test using medians, $P=$ 0.03). The partitioning of total ANPP between grasses and shrubs had a mean ratio of $0.97: 1$ (the maximum ratio was $1.5: 1$ and the minimum was $0.4: 1$ ). During the 10 years of simultaneous grass and shrub ANPP measurements, mean precipitation and its variability were slightly higher than the long-term means for the study site (mean and CV for a 24-yr period are $152 \mathrm{~mm} /$ yr and $32 \%$ ). Total ANPP varied more than threefold from the dry year of 1983 to the long-term mean precipitation year of 1985. Rain use efficiency (Le Houérou 1984) averaged $0.39 \mathrm{~g} \cdot \mathrm{m}^{-2} \cdot \mathrm{mm}^{-1}$ and its interannual CV was $27 \%$. Total ANPP was not significantly related to current-year precipitation $(n=10, R=0.59$, $P=0.08$ ).

Grasses and shrubs showed contrasting responses to precipitation (Fig. 1). Grass annual ANPP did not display any significant association with precipitation inputs (Fig. 1). The maximum correlation coefficient was observed for the precipitation in December. This value decreased as earlier months were considered.

Shrub annual ANPP was best accounted for by precipitation inputs during the previous $14 \mathrm{mo}$ and the fit was better than that for grasses (Fig. 1). Precipitation from October of the previous year to December of the current year explained $67 \%$ of shrub ANPP variation. The relationship with precipitation achieved its highest association when we considered periods $>10$ mo, i.e., March-December of the current year. The effect of precipitation was still significant even when two years were considered (23 mo).

Neither mean annual temperatures nor seasonal means were significantly associated with grass or shrub annual ANPP values (grass ANPP, $n=13, R<0.32$, $P>0.1$; shrub ANPP, $n=10, R<0.25, P>0.1)$. ANPP values of contiguous years were unrelated for grasses, shrubs, or the total community. We found a significant positive relationship between recent dead biomass of the current year and ANPP of the previous year for grasses $(n=10, R=0.74, P=0.013)$. We did not find any significant relationship between the partitioning of total ANPP between grasses and shrubs and total precipitation or temperature.

Minimum green biomass values for grass occurred during winter or early spring and averaged $11 \mathrm{~g} / \mathrm{m}^{2}$ (Fig. 2). Maximum values were achieved during late November or January and averaged $31 \mathrm{~g} / \mathrm{m}^{2}$. Dead biomass fluctuated within nearly the same range of values as green biomass. Dead biomass had its minimum dur- 
TABLE 2. Annual value for aboveground net primary production (ANPP), temperature, precipitation, and rain use efficiency (RUE = total production/precipitation) for the Occidental District of the Patagonian steppe.

\begin{tabular}{|c|c|c|c|c|c|c|}
\hline Year & $\begin{array}{c}\text { Grass } \\
\text { ANPP } \\
\left(\mathrm{g} \cdot \mathrm{m}^{-2} \cdot \mathrm{yr}^{-1}\right)\end{array}$ & $\begin{array}{c}\text { Shrub } \\
\text { ANPP } \\
\left(\mathrm{g} \cdot \mathrm{m}^{-2} .\right. \\
\left.\mathrm{yr}^{-1}\right)\end{array}$ & $\begin{array}{c}\text { Total } \\
\text { ANPP } \\
\left(\mathrm{g} \cdot \mathrm{m}^{-2} .\right. \\
\left.\mathrm{yr}^{-1}\right)\end{array}$ & $\begin{array}{c}\text { Temperature } \\
\left({ }^{\circ} \mathrm{C}\right)\end{array}$ & $\begin{array}{l}\text { Precipitation } \\
(\mathrm{mm} / \mathrm{yr})\end{array}$ & $\begin{array}{c}\text { RUE } \\
\left(\mathrm{g} \cdot \mathrm{m}^{-2} .\right. \\
\left.\mathrm{mm}^{-1}\right)\end{array}$ \\
\hline $1972 \dagger$ & 32.5 & $\ldots$ & $\ldots$ & $\ldots$ & 123 & $\cdots$ \\
\hline $1975 \ddagger$ & 48.7 & $\ldots$ & $\ldots$ & $\ldots$ & 174 & $\ldots$ \\
\hline $1983 \S$ & 10.6 & 10.8 & 21.4 & 8.8 & 55 & 0.39 \\
\hline $1984^{\circ}$ & 39.0 & 25.7 & 64.7 & 8.5 & 191 & 0.34 \\
\hline 1985 & 41.8 & 33.6 & 75.4 & 8.0 & 142 & 0.53 \\
\hline 1986 & 29.5 & 34.0 & 63.5 & 8.5 & 166 & 0.38 \\
\hline 1988 & 36.4 & 23.9 & 60.3 & 8.6 & 105 & 0.57 \\
\hline $1990 \|$ & 20.4 & $\ldots$ & $\ldots$ & 8.7 & 125 & $\ldots$ \\
\hline 1991 & 29.9 & $\ldots$ & $\ldots$ & 7.6 & 170 & $\ldots$ \\
\hline 1992 & 24.2 & $\ldots$ & $\ldots$ & 7.8 & 195 & $\ldots$ \\
\hline 1993 & 30.5 & 26.5 & 57.0 & 8.5 & 126 & 0.45 \\
\hline 1994 & 23.8 & 31.3 & 55.1 & 9.1 & 208 & 0.26 \\
\hline 1995 & 24.9 & 33.9 & 58.8 & 9.0 & 163 & 0.36 \\
\hline 1996 & 14.7 & 27.8 & 42.6 & 8.5 & 113 & 0.38 \\
\hline 1997 & 17.9 & 45.8 & 63.7 & 8.4 & 276 & 0.23 \\
\hline Mean & $28.3(26.9)$ & 29.3 & 56.2 & $8.5(8.4)$ & $155(155)$ & 0.39 \\
\hline $1 \mathrm{SD}$ & $10.4(9.9)$ & 9.0 & 14.8 & $0.4(0.3)$ & $52(58)$ & 0.11 \\
\hline $\mathrm{CV}(\%)$ & 36.8 (36.9) & 30.7 & 26.3 & $5.2(3.6)$ & $33.6(37.4)$ & 27.3 \\
\hline
\end{tabular}

Notes: Annual precipitation and temperature are the annual sum and mean for the period January-December prior to the production estimate. Mean, standard deviation, and coefficient of variation $(\mathrm{CV})$ were calculated considering all the values within a column. Values in parentheses were calculated considering only those years $(n=10)$ for which data were available for all of the variables.

† Data from Ares (1978).

\$ Data from Soriano et al. (1976).

§ Data (1983-1988) from Fernández et al. (1991).

|| Data (1990-1997) data collected by E. G. Jobbágy and O. E. Sala.

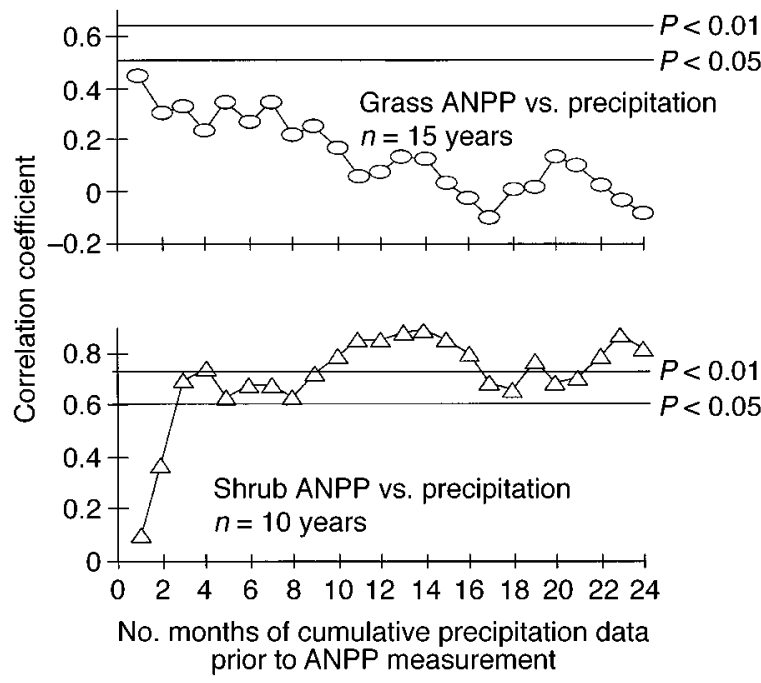

FIG. 1. The association between annual grass and shrub ANPP and precipitation for varying periods. The correlation between ANPP and precipitation was calculated considering 1-24 mo of precipitation data prior to the date of the annual productivity estimate (early January). Correlation levels that correspond to significance levels of $P<0.05$ and $P<0.01$ are indicated with horizontal lines. ing winter or early spring; however, during 1985 and 1995, it increased constantly throughout the whole year.

Most of the annual grass ANPP occurred between September and January (Fig. 3a). Mean grass production peaked during late October, when it reached 0.2 $\mathrm{g} \cdot \mathrm{m}^{-2} \cdot \mathrm{d}^{-1}$. February, March, and April were unproductive months. Grass senescence was constant during spring, summer, and fall and decreased in winter. During late December, mean curves of grass production and senescence crossed over, indicating the end of the green biomass accumulation period. Senescence was higher than production until late fall, when green biomass of grass begin to accumulate again. The integrals of production and senescence curves were not significantly different, indicating balance throughout the seven years of seasonal measurements. Production variability, measured as the coefficient of variation, peaked during the low productive period of late fall and early winter with a maximum $\mathrm{CV}$ of $250 \%$. The least variable period was coincident with the productivity peak of October-November with a CV of $61 \%$. The decay of production during the summer was accompanied by an increase of production variability that reached a $\mathrm{CV}$ of $130 \%$. (Fig. 3b). Senescence was more variable during winter, when the decay of biomass was low.

Grass production during winter (July-September) was positively associated with temperature in fall 


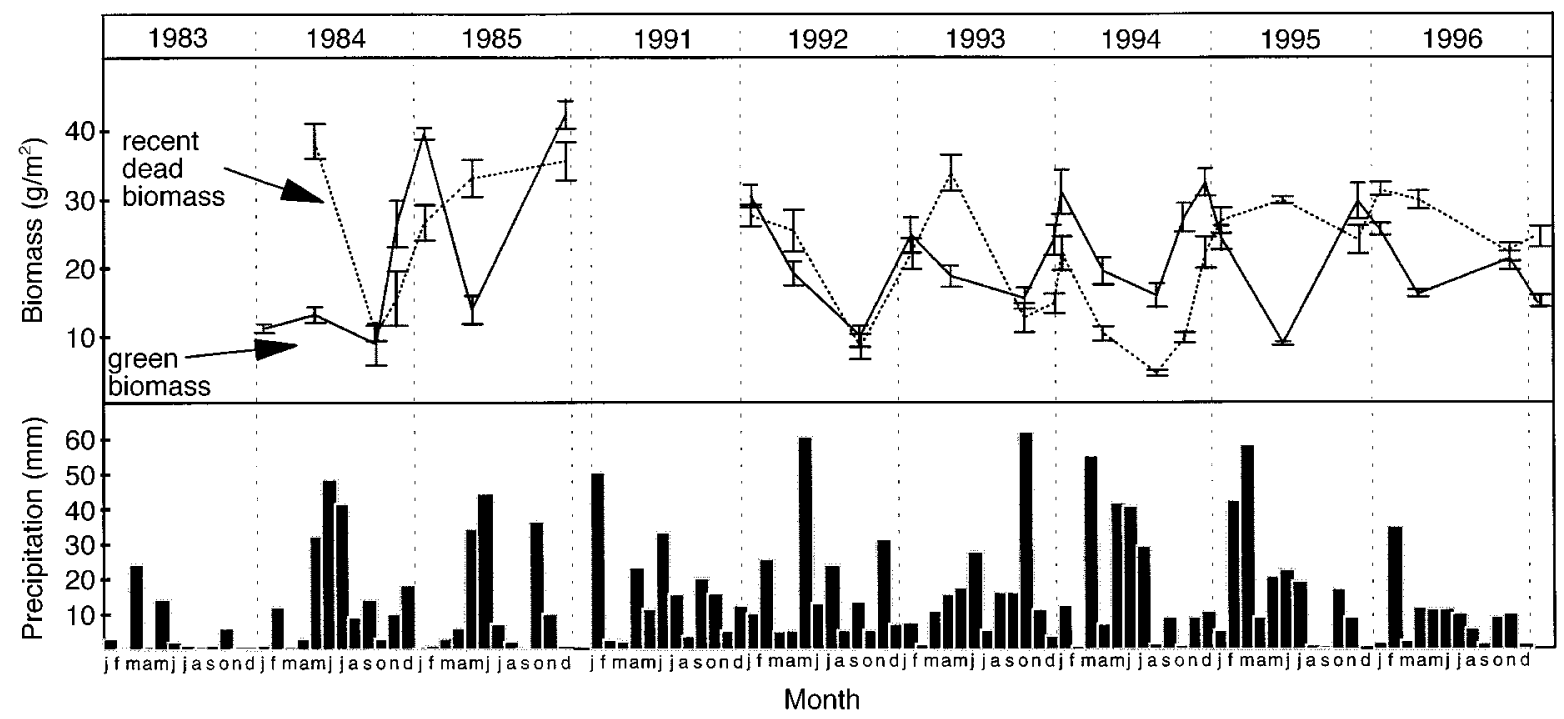

FIG. 2. Dynamics of green and recent-dead biomass of grasses and precipitation, by month, over nine years. The solid line represents green biomass, and the dotted line represents recent-dead biomass; biomass values are shown as mean \pm 1 SE, with $N=20$. Biomass values for 1984 and 1985 were obtained from Fernández et al. (1991).
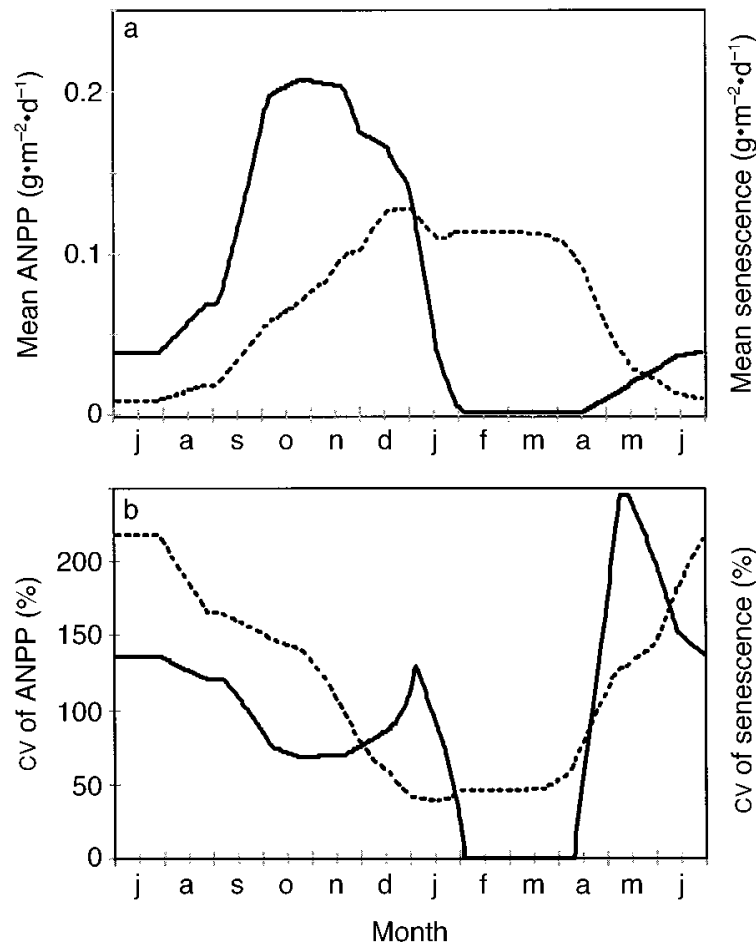

FIG. 3 Seasonal dynamics of grass production and senescence. (a) Mean daily grass ANPP (solid line) and senescence (dotted line) were estimated from frequent biomass harvests during 1984, 1985, 1992, 1993, 1994, 1995, and 1996. (b) Coefficient of variation of daily grass ANPP (solid line) and senescence (dotted line) among years.
(May-June, Table 3). During spring (October-December), grass production was positively associated with winter precipitation, and in summer it was positively associated with spring precipitation. Spring senescence was negatively associated with spring precipitation.

\section{Discussion}

Our specific questions 1 and 2 were focused on ANPP patterns at the annual scale. Both patterns of annual ANPP and their association with climate showed important contrasts between grasses and shrubs. Annual grass ANPP was not associated with precipitation. The highest correlation was observed for the precipitation input during December. In contrast, shrub ANPP was associated with precipitation inputs when the whole winter period was included in the summation of precipitation. Seasonal data on grass ANPP showed that, in part, the low correlation of ANPP and precipitation at the annual scale is the result of changing controls among seasons. Although fall temperature explained ANPP at the beginning of the growing season, precipitation during the second half of the year (July-December) explained the rest of the annual production by grasses.

The differences in the response of grass and shrub ANPP to precipitation can be explained by the different root distribution patterns of both functional groups. In the Occidental District of the Patagonian steppe, grasses have a shallow root system concentrated above 30 $\mathrm{cm}$ in the soil and absorb water mostly from this horizon (Soriano et al. 1987, Sala et al. 1989). The shallow layers of the soil from which this functional group extracts water become saturated with a small amount of water. The water-holding capacity of the upper 30 $\mathrm{cm}$ of this soil is only $24 \mathrm{~mm}$ (Paruelo and Sala 1995). 
TABLE 3. Correlation coefficient matrix for seasonal grass production and senescence vs. precipitation and temperature.

\begin{tabular}{|c|c|c|c|c|c|c|c|c|}
\hline \multirow[b]{2}{*}{ Season } & \multicolumn{4}{|c|}{ Precipitation } & \multicolumn{4}{|c|}{ Temperature } \\
\hline & Summer & Fall & Winter & Spring & Summer & Fall & Winter & Spring \\
\hline \multicolumn{9}{|l|}{ a) ANPP } \\
\hline Summer & -0.62 & 0.27 & 0.57 & 0.57 & 0.11 & -0.72 & -0.30 & -0.16 \\
\hline Fall & $\overline{-0.08}$ & 0.01 & 0.42 & 0.20 & $-\overline{0.26}$ & 0.52 & -0.32 & 0.18 \\
\hline Winter & 0.49 & $\overline{0.16}$ & -0.28 & 0.35 & 0.18 & $\overline{\mathbf{0 . 7 5}}$ & $\underline{0.27}$ & 0.00 \\
\hline Spring & -0.07 & 0.20 & $\mathbf{0 . 8 2}$ & -0.35 & 0.31 & -0.53 & $-\overline{0.71}$ & -0.49 \\
\hline \multicolumn{9}{|c|}{ b) Senescence } \\
\hline Summer & -0.39 & 0.52 & 0.58 & 0.24 & -0.08 & -0.27 & -0.50 & 0.57 \\
\hline Fall & 0.04 & -0.14 & 0.68 & 0.07 & 0.03 & 0.15 & -0.59 & 0.36 \\
\hline Winter & 0.06 & 0.50 & 0.59 & 0.14 & 0.70 & $-\overline{0.43}$ & -0.34 & 0.48 \\
\hline Spring & 0.40 & 0.15 & $\overline{0.63}$ & -0.80 & 0.68 & -0.05 & $\overline{-0.24}$ & -0.30 \\
\hline
\end{tabular}

Notes: We calculated the correlation between (a) ANPP and (b) senescence, for each season, and temperature and precipitation during the current season (underlined coefficients) and each of the previous three seasons (non-underlined coefficients). Seasons were defined as: summer, 1 January to $31 \mathrm{March}$; fall, 1 April to 30 June; winter, 1 July to 30 September; spring, 1 October to 31 December. Coefficients in boldface indicate significant associations at $P<0.05$.

This small water-holding capacity, in conjunction with high precipitation and low water absorption by plants during fall and winter, determines that full water recharge of the upper layers of the soil occurs almost every year (Paruelo and Sala 1995). We suggest that this is the main reason why the fluctuations of early precipitation inputs (those before July) do not affect grass ANPP. The long-term probability that the 10-20 $\mathrm{cm}$ soil layer will have a soil water potential exceeding $-1 \mathrm{MPa}$ is 1 during the winter and ranges between 0.2 and 0.3 during the summer (Paruelo and Sala 1995). The seasonal-scale analysis revealed that precipitation inputs after July have an effect on the ANPP levels of spring and summer. The fact that precipitation explains only a fraction of total annual ANPP results in a low correlation at the annual scale.

Shrubs concentrate most of their roots below $30 \mathrm{~cm}$ in the soil (Fernández and Paruelo 1988). Using the previous reasoning, this functional group with deep roots will be expected to respond to larger water inputs. The depth interval with a high density of shrub roots in the studied community has a water-holding capacity of $32 \mathrm{~mm}$ (Paruelo and Sala 1995), and to get there, water needs to wet first the upper layers of the soil that hold $24 \mathrm{~mm}$. This explains why shrub ANPP was associated with precipitation during winter and fall months. Manipulative experiments in the same ecosystem demonstrated that shrubs absorb water exclusively from deeper layers, whereas grasses absorb mostly from the uppermost layers (Sala et al. 1989). Experimental watering demonstrated the inability of shrubs to use summer water inputs (Golluscio et al. 1998). Using a water dynamics model for the Patagonian steppe, Paruelo and Sala (1995) showed that spring-summer precipitation had a high effect on grass annual transpiration, whereas fall-winter precipitation had a higher impact on shrub annual transpiration. The fact that precipitation affects grasses and shrubs in a different fashion explains the lack of association that we found between the annual ANPP of these two functional groups. This also implies that the conditions maximizing the production of one functional group may not necessarily maximize production of the other, explaining the low correlation between ANPP and annual precipitation and between the ANPP of shrubs and grasses. The response of one functional group may offset the response of the other.

An interesting structural aspect of shrubs and grasses in the study system is that the former have about half of the aboveground cover of the later (Fernández et al. 1991), but both have similar ANPP. The high spatial concentration of ANPP by shrubs in comparison to tussock grasses can be an important cause of the strong fertility island effect reported for shrub plants in other arid ecosystems (Schlesinger et al. 1996).

Neither previous-year precipitation nor previousyear grass ANPP had effects on current-year grass ANPP. These results indicate that grasses in the Occidental District of the Patagonian steppe do not have an important structural inertia, as was suggested for grasses in other ecosystems such as the North American short-grass steppe (Lauenroth and Sala 1992).

The total annual ANPP and the rain use efficiency (Le Houérou 1984) of the studied community were considerably higher than those of other rangelands in North America receiving $<200 \mathrm{~mm}$ of annual precipitation (Table 4). The variability of ANPP levels was also lower in Patagonia than in other rangelands. A possible cause of these differences is the equal contribution to total ANPP of two functional groups, grasses and shrubs, which use different soil water resources and have different environmental controls of ANPP.

Question 3 was focused on the seasonal dynamics of ANPP and senescence. Grass production and senescence showed different seasonal patterns. Grass production occurred during a narrow period in spring, whereas senescence was more evenly distributed throughout the year. The production peak occurred $\sim 2$ 
TABLE 4. Aboveground net primary production (ANPP) of described ecosystems receiving $<200 \mathrm{~mm}$ of annual precipitation.

\begin{tabular}{|c|c|c|c|c|c|c|c|c|}
\hline \multirow[b]{2}{*}{ Location } & \multirow[b]{2}{*}{ Vegetation type } & \multirow[b]{2}{*}{$\begin{array}{c}\text { Study } \\
\text { length } \\
(y r)\end{array}$} & \multicolumn{2}{|c|}{ Precipitation } & \multicolumn{2}{|c|}{ ANPP } & \multirow[b]{2}{*}{$\begin{array}{c}\mathrm{RUE} \dagger \\
\left(\mathrm{g} \cdot \mathrm{m}^{-2}\right. \\
\left.\mathrm{mm}^{-1}\right)\end{array}$} & \multirow[b]{2}{*}{ Reference } \\
\hline & & & $\begin{array}{c}\text { Mean } \\
(\mathrm{mm} / \mathrm{yr})\end{array}$ & $\begin{array}{l}\mathrm{CV} \\
(\%)\end{array}$ & $\begin{array}{c}\text { Mean } \\
\left(\mathrm{g} \cdot \mathrm{m}^{-2}\right. \\
\left.\mathrm{yr}^{-1}\right)\end{array}$ & $\begin{array}{c}\mathrm{CV} \\
(\%)\end{array}$ & & \\
\hline Oregon, USA & Bunchgrass steppe & 9 & 143 & 37 & 24.9 & 53 & 0.17 & Sneva and Hyder (1962) \\
\hline New Mexico, USA & Shrub steppe & 5 & 125 & 44 & 24.6 & 74 & 0.20 & Szarek (1979) \\
\hline New Mexico, USA & Grass steppe & 16 & 175 & 49 & 35.2 & 68 & 0.20 & Herbel et al. (1972) \\
\hline New Mexico, USA & Grass steppe & 16 & 186 & 49 & 50.9 & 59 & 0.27 & Herbel et al. (1972) \\
\hline New Mexico, USA & Grass steppe & 16 & 190 & 50 & 56.3 & 55 & 0.30 & Herbel et al. (1972) \\
\hline New Mexico, USA & Grass steppe & 16 & 187 & 50 & 37.0 & 82 & 0.20 & Herbel et al. (1972) \\
\hline Patagonia, Argentina & Grass-shrub steppe & 10 & 155 & 38 & 56.2 & 26 & 0.39 & This study \\
\hline
\end{tabular}

$\dagger$ Rain use efficiency.

mo after the precipitation peak. Green biomass accumulated from early spring to early summer because senescence was higher than production during the rest of the year.

Question 4 was focused on the controls of seasonal ANPP. At this temporal scale, grass ANPP was associated with temperature and precipitation. Almost the first half of the grass production period occurred during winter (July-September) and was associated with temperature during the previous season. The second half of the grass production period occurred during spring (October-December) and was explained by precipitation during the previous season (July-September). Production during summer was low, but still related to the previous season rainfall (October-November). Grass production showed transient maximum dynamics (sensu Seasted and Knapp 1993). Grass production had its maximum during a transition period in which its constraints shifted from temperature to water. Before and after this period, either temperature or water availability constrained grass production.

Our seasonal observations of ANPP in the Occidental District of Patagonia agree with plant phenology and growth data for the Great Basin rangelands in North America (Comstock et al. 1988, Comstock and Ehleringer 1992). Like Patagonia, the Great Basin is a cold, arid region that has its major precipitation input in winter, and a general feature of this type of ecosystem, is the interaction of temperature and precipitation shaping the seasonality of plant activity.

Variability of grass production does not have the same pattern as production itself (Fig. 3b). Variability has two maxima, one during late fall and early winter and a smaller one in January when production starts to decline. The minimum occurs during the core of the growing season. We suggest that the large variability in early winter is associated with variability in temperature. Because grasses explore the upper layers of the soil, which are usually refilled with water every year, there is low variability in production during the core of the production period (October-December), when there is neither temperature nor water limitation. We suggest that the second peak in variability is related to variability in summer precipitation. The end of the growing period for grasses seems to be determined by water availability. At this time of the year, stored water has been used up and production largely depends on current precipitation. The variability in summer precipitation would account for the second peak in production variability.

In this work, annual grass ANPP was estimated by the peak of green grass biomass measured during January. When we compared the annual estimates of grass ANPP based on the single January measurement of green biomass with more detailed annual estimates obtained by the summation of the seasonal ANPP values, we found no significant differences from a 1:1 match ( $n=7, R^{2}=0.80$; slope not different from 1 with $P$ $=0.12$, and intercept not different from 0 with $P=$ $0.33)$. In contrast, when recent-dead material was included in the single-measurement estimate of annual ANPP, values were much higher than the estimates obtained by seasonal summation. The significant association between current recent-dead biomass and previous-year green biomass indicated that there is a carryover of biomass from one year to the next. Therefore, the estimates of annual production considering green plus recent-dead biomass peaks overestimate production by a double count of biomass. Our result supports the use of peak green biomass for annual production estimates, in agreement with theoretical analyses of the errors associated with estimates of primary production derived from time series of biomass (Sala et al. 1988a, Biondini et al. 1991). In arid as well as in more humid ecosystems, there are two kinds of errors associated with production estimates; attempts to reduce one kind, always result in increases of the other (Sala et al. 1988a). Theoretical and empirical analyses indicate that if the purpose is to estimate annual primary production, peak green biomass is one of the methodological options with the smallest total error. The assumption that the peak of green biomass always occurs in January was not confirmed; during 1994 to 1996, for example, the peaks occurred in late November or December. Future measurements should concentrate in early December to early January for more accurate estimates. In the case of shrubs, we assumed that currentyear leaf and twig biomass accounted for annual ANPP. 
The correct identification of this plant material was confirmed by direct observations throughout several growing seasons, indicating that old tissue was not inflating our ANPP estimates. We can discard the possibility of underestimating ANPP because of leaf abscission, having observed that $M$. spinosum and $S$. $f$ laginoides retained their senesced leaves for more than a growing season, and A. campestris shed them during the fall, after the biomass harvests. A slight underestimation of shrub ANPP may be expected in our work, because we did not consider stem diameter changes of older branches. The use of current-year biomass accumulation at the end of the growing season as an estimate of ANPP has been successful in other arid shrublands (e.g., Ettershank et al. 1978), and avoids the overestimation errors associated with repeated sampling (Sala et al. 1988a).

There are no measurements of belowground net primary production (BNPP) for the study system. However, Soriano et al. (1987) described root growth seasonality and root biomass distribution for the three dominant grass species in the same site where our work has been conducted. Root in-growth cores located in the border of grass tussocks to a depth of $30 \mathrm{~cm}$ yielded a mean root production of $278 \mathrm{~g} / \mathrm{m}^{2}$ during spring (October-December). Root growth during the rest of the year was negligible (Soriano et al. 1987). This value needs to be considered as a maximum estimate of grass BNPP, because the location of samples close to individual plants and the enhancement of root production that can be caused by the in-growth method would produce a positive bias. If we consider this grass BNPP estimate, grass NPP would be $\sim 300 \mathrm{~g} \cdot \mathrm{m}^{-2} \cdot \mathrm{yr}^{-1}$ and the ratio of above- to belowground production would be $1: 10$. There are no root production data for shrubs in the Patagonian steppe, but we can assume that the above- to belowground production ratio is close to the 1:3 value reported by Caldwell et al. (1977) for two Great Basin shrublands. Based on this assumption, shrub NPP in our study system would be $\sim 120$ $\mathrm{g} \cdot \mathrm{m}^{-2} \cdot \mathrm{yr}^{-1}$. The contribution of other life-forms to total ecosystem NPP is negligible in the studied system. Forbs are the group next in importance following grasses and shrubs and their contribution to total biomass is $<4 \%$ (Golluscio et al. 1982, Golluscio and Sala 1993).

Our results give some initial basis for ANPP forecasting in the Occidental District of the Patagonian steppe. Our study ecosystem, at least during the period analyzed, has more stable production levels than other rangelands that receive similar precipitation. The more stable components of total ANPP are shrubs. The annual ANPP of shrubs (nearly one-half of the total ANPP) can be predicted with 6 months of anticipation considering the precipitation inputs during the previous spring, summer, and fall (Fig. 1). At the seasonal scale, winter grass ANPP can be predicted several months in advance by considering April-May-June temperature.
Spring and summer grass ANPP can be predicted some months in advance by considering July-September or October-December precipitation, respectively. Our data set does not allow a rigorous parameterization of these relationships, but indicates that longer term observations and/or manipulations of water availability and temperature may yield valuable predictive tools for grazing management in the Patagonian steppe.

\section{ACKNOWLEDGMENTS}

We wish to thank Roberto Fernández Alduncin for his assistance with the compilation of previous data. Martín Oesterheld's suggestions improved the presentation and discussion of primary production patterns. Rodolfo Golluscio and José Paruelo provided insightful comments. Many people helped us with the biomass harvests: special thanks to A. Bisigato, J. Mercau, M. Nogués, P. Roset, V. Sigal, and J. Vrsalovic. Pedro Gundel assisted us with sample processing in the lab. This work was jointly funded by the U.S. National Science Foundation Cross Site LTER Project DEB-9416815, the University of Buenos Aires, the InterAmerican Institute for Global Change Research, and FONCyT-CONICET PICT 0277 and PMT-SID 0609. E. G. Jobbágy was supported by a graduate student research fellowship from the University of Buenos Aires. We dedicate this paper to the memory of Professor Alberto Soriano.

\section{Literature Cited}

Ares, J. L. 1978. Un modelo de la dinámica de la biomasa aérea de tres especies dominantes de un pastizal patagónico. Deserta 5:45-56.

Biondini, M. E., W. K. Lauenroth, and O. E. Sala. 1991. Correcting estimates of net primary production: Are we overestimating plant production in rangelands? Journal of Range Management 44:194-197.

Brown, M. B., and A. B. Forsythe. 1974. Robust tests for the equality of variances. Journal of the American Statistics Association 69:364-367.

Caldwell, M. M., R. S. White, R. T. Moore, and L. B. Camp. 1977. Carbon balance, productivity, and water use of coldwinter desert shrub communities dominated by $\mathrm{C}_{3}$ and $\mathrm{C}_{4}$ species. Oecologia 29:275-300.

Chapin, F. S. 1993. Functional role of growth forms in ecosystem and global processes. Pages 287-312 in J. R. Ehleringer and C. B. Field, editors. Scaling physiological processes: Leaf to globe. Academic Press, London, UK.

Comstock, J. P., T. A. Cooper, and J. R. Ehleringer. 1988. Seasonal patterns of canopy development and carbon gain in nineteen warm desert shrub species. Oecologia 75:327325 .

Comstock, J. P., and J. R. Ehleringer. 1992. Plant adaptations in the Great Basin and Colorado Plateau. Great Basin Naturalist 3:195-215.

Deffosé, G. E., M. B. Bertiller, and J. O. Ares. 1990. Aboveground phytomass dynamics in a grassland steppe of $\mathrm{Pa}-$ tagonia. Journal of Range Management 43:157-160.

Ettershank, G., J. Ettershank, M. Bryant, and W. G. Whitford. 1978. Effects of nitrogen fertilization on primary production in a Chihuahuan desert ecosystem. Journal of Arid Environment 1:135-139.

Fernández, A. R. J., and J. M. Paruelo. 1988. Root systems of two Patagonian shrubs: A quantitative description using a geometrical method. Journal of Range Management 41: $220-223$.

Fernández, A. R. J., O. E. Sala, and R. A. Golluscio. 1991. Woody and herbaceous aboveground production of a Patagonian steppe. Journal of Range Management 44:434437.

Golluscio, R. A., R. J. C. León, and S. B. Perelman. 1982. 
Caracterización fitosociológica de la estepa del oeste del Chubut. Su relación con el gradiente ambiental. Boletín de la Sociedad Argentina de Botánica 21:299-324.

Golluscio, R. A., and O. E. Sala. 1993. Plant functional types and ecological strategies in Patagonian forbs. Journal of Vegetation Science 4:839-846.

Golluscio, R. A., O. E. Sala, and W. K. Lauenroth. 1998. Differential use of large summer rainfall events by shrubs and grasses: A manipulative experiment in the Patagonian steppe. Oecologia 115:17-25.

Greig-Smith, P. 1983. Quantitative plant ecology. Third edition, Blackwell, Oxford, UK.

Herbel, C. H., F. N. Ares, and R. A. Wright. 1972. Drought effects on semidesert grassland range. Ecology 53:10841093.

Jobbágy, E. G., J. M. Paruelo, and R. J. C. León. 1995. Estimación del régimen de precipitación a partir de la distancia a la cordillera en el noroeste de la Patagonia. Ecología Austral 5:47-53.

Lauenroth, W. K. 1979. Grassland primary production: North American grasslands in perspective. Pages 3-24 in R. N. French, editor. Perspectives in grassland ecology. Ecological Studies, Volume 32. Springer-Verlag, New York, New York, USA.

Lauenroth, W. K., and O. E. Sala. 1992. Long-term forage production of North American shortgrass steppe. Ecological Applications 2:397-403.

Le Houérou, H. N. 1984. Rain-use efficiency: A unifying concept in arid land ecology. Journal of Arid Environments $7: 1-35$.

Le Houérou, H. N., R. L. Bingham, and W. Skerbek. 1988 Relationship between the variability of primary production and the variability of annual precipitation in world arid lands. Journal of Arid Environments 15:1-18.

McNaughton, S. J., M. Oesterheld, D. A. Frank, and K. J. Williams. 1989. Ecosystem level patterns of primary productivity and herbivory in terrestrial habitats. Nature 341: 142-144.

McNaughton, S. J., O. E. Sala, and M. Oesterheld. 1993. Comparative ecology of African and South American arid to subhumid ecosystems. Pages 548-567 in P. Goldblatt, editor. Biological relationships between Africa and South America. Yale University Press, New Haven, Connecticut, USA.

Odum, E. P. 1971. Fundamentals of ecology. Saunders, Philadelphia, Pennsylvania, USA.

Paruelo, J. M., M. R. Aguiar, and R. A. Golluscio. 1988. Soil water availability in the Patagonian arid steppe: gravel content effect. Arid Soil Research and Rehabilitation 2:67-74.

Paruelo, J. M., E. G. Jobbágy, O. E. Sala, W. K. Lauenroth, and I. C. Burke. 1998. Functional and structural convergence between North and South America. Ecological Applications 8:194-200.

Paruelo, J. M., and O. E. Sala. 1995. Water losses in the Patagonian steppe: a modeling approach. Ecology 76:510 520.
Sala, O. E., M. E. Biondini, and W. K. Lauenroth. 1988a. Bias in estimates of primary production: an analytical solution. Ecological Modelling 44:43-55.

Sala, O. E., R. A. Golluscio, W. K. Lauenroth, and A. Soriano. 1989. Resource partitioning between shrubs and grasses in the Patagonian steppe. Oecologia 81:501-505.

Sala, O. E., W. J. Parton, L. A. Joyce, and W. K. Lauenroth. $1988 b$. Primary production of the central grassland region of the United States. Ecology 69:40-45.

Schlesinger, W. H., J. A. Raikes, A. E. Hartley, and A. F. Cross. 1996. On the spatial pattern of soil nutrients in desert ecosystems. Ecology 77:364-374.

Schultz, B. B. 1985. Levene's test for relative variation. Systematic Zoology 34:449-456.

Seasted, T. R., and A. K. Knapp. 1993. Consequences of nonequilibrium resource availability across multiple time scales: The transient maxima hypothesis. American Naturalist 141:621-633.

Singh, J. S., W. K. Lauenroth, and R. K. Steinhorst. 1975. Review and assessment of various techniques for estimating net aerial primary production in grassland from harvest data. Botanical Review 41:181-232.

Smoliak, S. 1986. Influence of climatic conditions on production of Stipa-Bouteloua over a 50-year period. Journal of Range Management 39:100-103.

Sneva, F. A., and D. M. Hyder. 1962. Estimating herbage production on semiarid ranges in the Intermountain region. Journal of Range Management 15:88-93.

Soriano, A. 1956. Los Distritos Florísticos de la Provincia Patagónica. Revista de Investigaciones Agropecuarias 10: 323-347.

Soriano, A. 1983. Deserts and semi-deserts of Patagonia. Pages 432-460 in N. E. West, editor. Temperate deserts and semideserts. Elsevier, Amsterdam, The Netherlands.

Soriano, A., H. A. Alippe, O. E. Sala, T. M. Schlichter, C. P. Movia, R. J. C. León, R. Trabucco, and V. A. Deregibus. 1976. Ecología del pastizal de coirón amargo (Stipa spp.) del sudoeste de Chubut. Academia Nacional de Agronomía y Veterinaria 30:1-28.

Soriano, A., R. A. Golluscio, and E. H. Satorre. 1987. Spatial heterogeneity of the root systems of grasses in the Patagonian steppe. Bulletin of the Torrey Botanical Club 114: 103-108.

Soriano, A., O. E. Sala, and S. B. Perelman. 1994. Patch structure and dynamics in a Patagonian arid steppe. Vegetatio 111:127-135.

Szarek, S. R. 1979. Primary production in four North American deserts: indices of efficiency. Journal of Arid Environments 2:187-209.

Webb, W. L., W. K. Lauenroth, S. R. Szarek, and R. Kinerson. 1983. Primary production and abiotic controls in forests, grasslands, and desert ecosystems in the United States. Ecology 64:134-151.

Webb, W. L., S. R. Szarek, W. K. Lauenroth, R. Kinerson, and M. Smith. 1978. Primary production and water use on native forest, grassland, and desert ecosystems. Ecology 59:1239-1247. 